УДК 342.7:614.2:354.1

DOI https://doi.org/10.51989/NUL.2021.4.9

\title{
РЕАЛІЗАЦІЯ ПРАВА ПАЦІЄНТА НА ДОПУСК ДО НЬОГО ВІДВІДУВАЧІВ
}

\author{
Серьогіна Наталія Олексіївна, \\ orcid.org/0000-0002-4491-4723 \\ Web of Science Researcher ID ABC-2638-2020 \\ Scopus Author ID: 57221470874 \\ кандидат юридичних наук, доцент, \\ начальник відділу моніторингу якості діяльності \\ Національного університету охорони здоров'я імені П. Л. Шупика
}

У статті здійснено аналіз стану реалізації прав пацієнтів на допуск до них відвідувачів. Доцільність проведеного аналізу пояснюється високим суспільним резонансом у частині застосування норм законодавства, що дозволяють такі відвідування. Наголошено, що в чинному законодавстві не визначено зміст таких термінів, як «відділення інтенсивної терапії», «реанімація», що дозволяє тлумачити їх на власний розсуд окремої особи. Досліджено зміст ст. 287 Цивільного кодексу України та п. «к» 4. 1 ст. 6 Закону України «Основи законодавства України про охорону здоров'я», які визначають коло осіб, які можуть бути допущеними до осіб, які перебувають на стаціонарному лікуванні. Наголошено, що норми ст. 287 ЦК України є нормами прямої дії і не посилаються на інші нормативно-правові акти, які 6 мали регулювати спосіб їі реалізації. Проаналізовано норми Наказу Міністерства охорони здоров'я України «Про затвердження Порядку допуску відвідувачів до пацієнтів, які перебувають на стаціонарному лікуванні у відділенні інтенсивної терапії» від 15.06.2016 p. № 592. Зосереджено увагу на тому, що в наказі № 592 не враховано думку пацієнтів, які можуть не бажати присутності відвідувачів чи їхньої допомоги, та окреслено можливі наслідки таких дій. Доведено, що наразі відсутній нормативно-правовий акт, який визначав би порядок госпіталізації, лікування, медичного спостереження за хворими на інфекційні хвороби, крім хворих на туберкульоз. Зазначено, що доцільно оновити Вимоги до дизайну зони перебування пацієнтів з урахуванням міжнародних вимог та права на особистий простір. У результаті проведеного дослідження виявлено ряд колізій, які спричиняють виникнення спірних ситуацій, та запропоновано шляхи усунення цих прогалин, зокрема в частині кола осіб, яких може бути допущено до пацієнта, та правил відвідування.

Ключові слова: права пацієнта, охорона здоров'я, відділення інтенсивної терапії, реанімація, Цивільний кодекс, актуальні проблеми публічного права.

\section{Serohina Nataliia. Exercise of the patient's right to receive visitors}

The article analyzes the state of realization of patients' rights to admit visitors to them. The expediency of the analysis is explained by the high public response in terms of the application of legislation that allows such visits. It is emphasized that the current legislation does not define the meaning of such terms as "intensive care unit", "resuscitation", which allows to interpret their definitions at the discretion of the individual. The content of Art. 287 of the Civil Code of Ukraine and paragraph "k" Part 1 of Art. 6 of the Law of Ukraine "Fundamentals of the legislation of Ukraine on health care" rights that determine the range of persons who may be admitted to persons undergoing inpatient treatment. It is emphasized that the rules of Art. 287 of the Civil Code of Ukraine are the norms of direct action and do not refer to other regulations that should regulate the method of its implementation. The norms of the Order of the Ministry of Health of Ukraine "On approval of the Procedure for admission of visitors to patients in inpatient treatment in the intensive care unit" dated 15.06.2016 лізова 592. The focus is on the fact that the order №592 does not take into account the views of patients who may not want the presence of visitors, the patient may not accept the help of the visitor and outline the possible consequences of such actions. It is proved that currently there is no normative-legal act that would determine the order of hospitalization, treatment, medical supervision of patients with infectious diseases, except for patients with tuberculosis. It is noted that it is advisable to update the requirements for the design of the area of patients, taking 
into account international requirements and the right to privacy. The study identified a number of conflicts that cause controversial situations and suggested ways to address these gaps, particularly in terms of the number of people who can be admitted to the patient and the rules of attendance.

Key words: patient rights, health care, intensive care unit, resuscitation, Civil Code, current issues of public law.

3 метою реалізації права пацієнта на допуск до нього сторонніх осіб було видано Наказ Міністерства охорони здоров'я України «Про затвердження Порядку допуску відвідувачів до пацієнтів, які перебувають на стаціонарному лікуванні у відділенні інтенсивної терапії» від 15.06.2016 р. № 592 [1] (далі - Наказ 592), у преамбулі якого зазначено, що наказ видано «відповідно до статей 6, 64 Основ законодавства України про охорону здоров'я, статті 287 Цивільного кодексу України <...> 3 метою покращення надання медичної допомоги та дотримання прав пацієнтів у відділенні інтенсивної терапії».

у переважній більшості усталеним визначенням про те, що таке відділення інтенсивної терапії (далі - ВIT) та реанімації (також просто реанімація чи відділення інтенсивної терапії та анестезіології або інша подібна назва), $\epsilon$ таке: «місце, де надають екстрену допомогу пацієнтам у важкому стані, які потребують цілодобового догляду». Однак закріпленої в законодавстві норми, яка конкретно визначає зміст цього терміна, немає, що дозволяє використання інших визначень на власний розсуд окремої особи. Єдиним нормативно-правовим актом, в якому ми все ж таки зустріли визначення термінів, $\in$ Державні будівельні норми В.2.2-10-2001 «Будинки і споруди. Заклади охорони здоров'я» (далі - ДБН В.2.2-10-2001), затверджені Наказом Держбуду України від 4 січня 2001 р. № 2 і введені в дію з 1 квітня 2001 р., які жодного разу не переглядались, зокрема:

- бокс реанімаційний - окрема група приміщень, що організується у зв'язку 3 відсутністю відділення реанімації та інтенсивної терапії і призначається для проведення комплексу лікувальних заходів, націлених на відновлення згасаючих або тільки що згаслих життєвих функцій організму;

- реанімація - комплекс лікувальних заходів, спрямованих на відновлення зга- саючих або тільки що згаслих життєво важливих функцій організму;

- палата інтенсивної терапії - приміщення в складі палатного відділення, призначене для догляду і лікування тяжко хворих [2].

Наведені визначення не в повній мірі збігаються 3 наведеним нами вище терміном, який застосовується в переважній більшості випадків.

Зміст норм чинного законодавства в частині визначення прав особи на медичну допомогу, інформацію про стан свого здоров'я, таємницю про стан здоров'я, на допуск сторонніх осіб визначається цілою низкою нормативно-правових актів.

Право пацієнта, який перебуває на стаціонарному лікуванні в закладі охорони здоров'я, на допуск до нього «інших медичних працівників, членів сім'ї, опікуна, піклувальника, нотаріуса та адвоката, а також священнослужителя для відправлення богослужіння та релігійного обряду», міститься в пункті «К» ч. 1 ст. 6 Закону України «Основи законодавства України про охорону здоров'я» від 9.11.1992 р. № 2801-XII [3] (далі Закон № 2801), аналогічна норма міститься в ст. 287 Цивільного кодексу України від 16.01.2003 р. № 435-IV [4] (далі ЦК України), в якій визначено, що фізична особа, яка перебуває на стаціонарному лікуванні в закладі охорони здоров'я, «має право на допуск до неї інших медичних працівників, членів сім'ї, опікуна, піклувальника, нотаріуса та адвоката, священнослужителя для відправлення богослужіння та релігійного обряду».

Зазначеними законами чітко окреслено коло осіб, які можуть бути допущеними до осіб, які перебувають на стаціонарному лікуванні.

Водночас абз. 1 п. 2 Положення, затвердженого Наказом № 592, який $\epsilon$ підзаконним нормативно-правовим актом і має нижчу юридичну силу, ніж ЦК України та Закон 2801, містить таку норму: 
«забезпечити пацієнтам, які перебувають на лікуванні у ВIT, право на допуск до них відвідувачів 24 години на добу в будь-який день тижня згідно з правилами, визначеними цим Порядком» [1]. Зазначена норма положення тлумачиться МО3 України так: «відвідувачем може бути будь-яка особа незалежно від родинних стосунків» [5], що порушує норми ст. 287 ЦК України та ст. 6 Закону № 2801.

ч. 3 ст. 39 Закону 2801 передбачає, що «якщо інформація про хворобу пацієнта може погіршити стан його здоров'я або погіршити стан здоров'я фізичних осіб, визначених частиною другою цієї статті, зашкодити процесові лікування, медичні працівники мають право надати неповну інформацію про стан здоров'я пацієнта, обмежити можливість їх ознайомлення 3 окремими медичними документами». У свою чергу ст. 39-1 наголошує на тому, що «пацієнт має право на таємницю про стан свого здоров'я, факт звернення за медичною допомогою, діагноз, а також про відомості, одержані під час його медичного обстеження» [3]. У Наказі № 592 не враховано думку пацієнтів, які можуть не бажати присутності відвідувачів, пацієнту може бути не прийнятною поміч відвідувача, у такому випадку це може збільшити стрес як самого пацієнта, так і відвідувача, а також інших пацієнтів, які знаходяться у відділенні. Інші пацієнти, які знаходяться в палаті, не захищені від відвідувачів, що також порушує їхнє право на приватність. Саме реалізація цих прав пацієнта потребує його однозначної згоди на відвідування. На нашу думку, також доцільно запровадити можливість «ізоляції» відвідувача з відвідуваним від решти пацієнтів.

Необхідно звернути увагу на те, що норми ст. 287 ЦК України $\epsilon$ нормами прямої дії і не посилаються на інші нормативно-правові акти, які 6 мали регулювати спосіб ії реалізації. Аналізуючи зміст цієї статті, необхідно звернутись до ст. 22 Закону «Про захист населення від інфекційних хвороб» від 06.04.2000 р. № 1645-III [6], яка містить норми щодо забезпечення санітарного та епідеміологічного благополуччя людей, прав людини на життя та здоров'я. Враховуючи спеціальний характер зазначеної норми, вона підлягає переважному застосуванню перед ст. 287 ЦК України. Відповідно до ст. 22 Закону «Про захист населення від інфекційних хвороб» умови перебування хворих на інфекційні хвороби у відповідних закладах охорони здоров'я та наукових установах визначаються спеціально уповноваженим центральним органом виконавчої влади з питань охорони здоров'я.

П. 8 Наказу № 592 містить лише декларативну норму: «відвідувачі зобов'язані утримуватись від відвідування паці$\epsilon н т а$, якщо в них спостерігаються прояви інфекційних захворювань або вони нещодавно мали контакт з носієм інфекційного захворювання, який може створити загрозу для здоров'я пацієнтів BIT». Однак не всі інфекційні хвороби мають зовнішні прояви, а відвідувачі не завжди $\epsilon$ свідомими і дійсно виконують цю норму, тому доцільною $€$ конкретизація норми, зокрема в період пандемії, спричиненої COVID-19 [1].

Під час перебування на стаціонарному лікуванні особливо гостро постає питання про збереження права на приватність. Право пацієнта на недоторканність особистого життя реалізується через: право на конфіденційність інформації, право на анонімність обстеження, право на таємницю листування, телефонних переговорів та інших повідомлень у разі перебування в стаціонарній установі охорони здоров'я.

Також $€$ доцільним, на нашу думку, більш детально врегулювати відвідування пацієнтів, які мають інфекційні хвороби. У Положенні, затвердженому Наказом 592, взагалі немає обмежень щодо хворих на складні форми туберкульозу та інші інфекційні захворювання. Зокрема, відповідно до ст. 10 Закону України від 05.07.2001 р. № 2586-III «Про протидію захворюванню на туберкульоз», «хворим на заразні форми туберкульозу забезпечується госпіталізація до протитуберкульозних закладів. У разі відмови хворих на заразні форми туберкульозу від госпіталізації їх лікування може проводитися амбулаторно за можливості їх ізоляції в домашніх умовах», а ст. 20 передбачає «можливість спілкування з членами сім'ї та іншими особами з дотриманням протиепідемічного режиму» [7]. 
Наразі відсутній нормативно-правовий акт, який визначав би порядок госпіталізації, лікування, медичного спостереження за хворими на інфекційні хвороби, крім хворих на туберкульоз.

У контексті підвищення рівня безпеки пацієнтів та з метою уникнення колізій у законодавстві вважаємо за доцільне внести такі зміни та доповнення до Наказу № 592:

1) доповнити п. 2 Порядку і викласти в редакції, що відповідає вимогам ЦК України та ЗУ № 2801: «До пацієнта можуть бути допущені за його вимогою або згодою інші медичні працівники, члени сім'і, опікуни, піклувальники, нотаріус та адвокат, а також священнослужитель для відправлення богослужіння та релігійного обряду. Інші особи можуть бути допущені за згодою лікаря та пацієнта тільки у випадку, якщо користь від відвідування буде перевищувати потенційний ризик для пацієнта.

Виключення становлять пацієнти до 14 років, згоду на відвідування яких надають батьки або особи, що їх замінюють» ;

2) доповнити п. 8 Порядку нормами такого змісту: «відвідування пацієнтів у період пандемії COVID-19 дозволяється за умови наявності одного з таких документів:

- документ про вакцинацію від COVID-19, зроблений не раніше ніж за 14 днів до відвідування пацієнта;

- документ, який засвідчує, що особа перехворіла на COVID-19 протягом останніх шести місяців;

- негативний ПЛР-тест на коронавірус, зроблений не пізніше ніж за 72 години до відвідування;

- експрес-тест на визначення антигену SARS-CoV-2, зроблений не пізніше ніж за 48 годин до відвідування;

- виключення може бути встановлено лише в тому випадку, якщо пацієнт знаходиться в критичному стані;

3) абз. 10 доповнити словами: «У випадку перешкоджання з боку відвідувача проведенню дій медичного характеру головний, лікуючий або черговий лікар має право обмежити допуск такого відвідувача до пацієнта»;
4) зважаючи на відсутність інфекційних боксів у більшості реанімацій, абз. 7 доповнити словами: «Відвідувачі зобов'язані одягати медичні маски та захисний одяг, який використовуватиметься лише у відділенні»;

5) доповнити такими нормами «Відвідувачам забороняється без дозволу медичного персоналу давати пацієнту самостійно ліки і трави, поїти та годувати його»;

«з метою уникнення проявів алергії, створення дискомфорту для пацієнтів відвідувачам заборонено користуватися парфумами, косметичними засобами або милом із сильним запахом, палити перед тим, як зайти у ВIТ»;

«з метою дотримання прав пацієнтів забороняється фото- та відео-зйомка палати, медичного персоналу, пацієнтів та інших відвідувачів. Під час відвідування звук телефону повинен бути вимкнений. Забороняється голосно розмовляти в палаті»;

6) Станом натепер вимоги до приміщень зони перебування пацієнтів відповідно до ДБН В.2.2-10-2001 такі:

- одномісні палати - не передбачено;

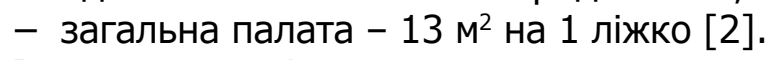

Водночас у міжнародних нормативноправових актах містяться зовсім інші вимоги, зокрема:

- одномісна плата 23,3 м² (відповідно до Настанови-SCCM-2012) та від 25 м² (відповідно до Рекомендацій ESICM-2011);

- загальна палата на одне IT-ліжко 20 м² $^{2}$ (відповідно до НастановиSCCM-2012) та 20,9 м² (відповідно до Рекомендацій ESICM-2011) [8].

Враховуючи міжнародні вимоги та право на особистий простір, доцільно оновити Вимоги до дизайну зони перебування пацієнтів: загальна площа ВIT повинна у 2,5-3 рази перевищувати сумарну площу зон, призначених для перебування пацієнтів. Площа індивідуальних зон перебування пацієнтів - не

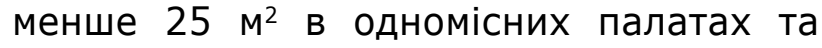

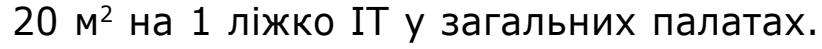
Не менше 2,5 м простору довкола ліжка пацієнта потрібно для вільного переміщення персоналу та обладнання. 


\section{ЛITEPATУPA:}

1. Про затвердження Порядку допуску відвідувачів до пацієнтів, які перебувають на стаціонарному лікуванні у відділенні інтенсивної терапії : Наказ МОЗ України від 15.06.2016 р. № 592. URL: https://zakon.rada.gov.ua/laws/show/z0883-16\#Text (дата звернення: 20.07.2021).

2. Державні будівельні норми України. Будинки та споруди. Заклади охорони здоров'я. ДБН В. 2.2-10-2001. URL: http://www.medconsulting.com.ua/f/nakazu_moz/others/DBN. Zaklad_OZ.pdf

3. Основи законодавства України про охорону здоров'я : Закон України від 9.11.1992 р. № 2801-XII. URL: https://zakon.rada.gov.ua/laws/show/2801-12\#n55 (дата звернення: 20.07.2021).

4. Цивільний кодекс України : Закон України від 16.01.2003 р. № 435-IV. URL: https:// zakon.rada.gov.ua/laws/show/435-15\#n1575 (дата звернення: 20.07.2021)

5. Відкриті «реанімації»: Як скористатись своїм правом і підтримати пацієнта у відділенні інтенсивної терапії. URL: https://moz.gov.ua/article/health/vidkriti-reanimacii-jak-skoristatissvoim-pravom-i-pidtrimati-pacienta-u-viddilenni-intensivnoi-terapii

6. Про захист населення від інфекційних хвороб : Закон України 06.04.2000 р. № 1645-III. URL: https://zakon.rada.gov.ua/laws/show/1645-14\#Text (дата звернення: 20.07.2021)

7. Про протидію захворюванню на туберкульоз : Закон України від 05.07.2001р. № 2586-III. URL: https://zakon.rada.gov.ua/laws/show/2586-14\#Text (дата звернення: 20.07.2021)

8. Guidelines for intensive care unit design / D. R. Thompson, D. K. Hamilton, C. D. Cadenhead, S. M. Swoboda [et al.]. Crit. Care Med. 2012. Vol. 40. № 5. P. 1586-1600; Guidelines/Practice Parameters Committee of the American College of Critical Care Medicine, Society of Critical Care Medicine Guidelines for intensive care unit design. Crit. Care Med. 1995. Vol. 23. P. 582-588. 